\title{
PENGARUH KOMPETENSI GURU TERHADAP KOMITMEN PROFESIONAL DAN DAMPAKNYA PADA KINERJA SERTA KEPUASAN KERJA GURU MATEMATIKA SMP DAN MTS
}

\author{
Zuhdy Tafqihan ${ }^{1)}$, Suryanto ${ }^{2)}$ \\ STAIN Ponorogo ${ }^{1)}$, Universitas Negeri Yogyakarta ${ }^{2)}$ \\ zuhdy.tafqihan@ gmail.com ${ }^{1)}$, suryanto@ uny.ac.id ${ }^{2)}$
}

\begin{abstract}
Abstrak
Penelitian ini bertujuan untuk memperoleh model hubungan kausalitas dari variabel-variabel kompetensi, komitmen profesional, kinerja dan kepuasan kerja guru matematika. Populasi dalam penelitian ini adalah seluruh guru matematika SMP dan MTs di Kabupaten Ponorogo yang berjumlah 262 orang. Sampel sejumlah 82 orang ditentukan melalui teknik two stage cluster random sampling. Instrumen penelitian ini adalah kuesioner dan lembar penilaian/observasi. Kuesioner digunakan untuk mengumpulkan data komitmen profesional dan kepuasan kerja guru matematika, sedangkan lembar penilaian/observasi digunakan untuk mengumpulkan data kompetensi dan kinerja guru matematika. Data yang diperoleh dianalisis dengan metode Structural Equation Modeling (SEM).Hasil penelitian menunjukkan bahwa: (1) terdapat pengaruh positif kompetensi terhadap komitmen profesional sebesar $15,9 \%$; (2) terdapat pengaruh positif kompetensi terhadap kinerja sebesar 63,6\%; (3) terdapat pengaruh positif komitmen profesional terhadap kinerja sebesar 15,9\%; dan (4) terdapat pengaruh positif komitmen profesional terhadap kepuasan kerja sebesar 37,8\%. Hasil-hasil penelitian di atas dapat mengkonfirmasi kesimpulan penelitian-penelitian sebelumnya.
\end{abstract}

Kata kunci: kompetensi guru, komitmen profesional, kinerja, kepuasan kerja, Structural Equation Modeling (SEM)

\section{THE EFFECT OF TEACHER COMPETENCIES ON PROFESSIONAL COMMITMENT AND ITS IMPACT ON THE PERFORMANCE AND JOB SATISFACTION OF SMP AND MTS MATHEMATICS TEACHERS}

\begin{abstract}
The aim of this study is to develop the causality relationships model among competencies, professional commitment, performance and job satisfaction of mathematics teachers. The population of this research is all SMP and MTs mathematics teachers in Ponorogo District totaling 262 teachers. A sample of 82 teachers was established using the two stage cluster random sampling technique. The instruments of the data collection were a questionnaire and appraisal/observation sheet. The questionnaire was used to collect the data on professional commitment and job satisfaction, while the appraisal/observation sheet was used to collect the data on competencies and performance. The data were analyzed using the Structural Equation Modeling (SEM) quantitative analysis. The research findings show that: (1) there is a positive effect of competencies on professional commitment, that is $15.9 \%$; (2) there is a positive effect of competencies on performance, that is $63.6 \%$; (3) there is a positive effect of professional commitment on performance, that is 15.9\%; and (4) there is a positive effect of professional commitment on job satisfaction, that is $37.8 \%$. The findings confirm the conclusion of previous researchs.
\end{abstract}

Keywords: teacher competencies, professional commitment, performance, job satisfaction, Structural Equation Modeling (SEM) 


\section{PENDAHULUAN}

Sosok guru memang selalu menjadi perhatian dikarenakan dampak kehadirannya amatlah nyata dirasakan semua pihak. Para orang tua akan merasakan kehadiran guru karena guru adalah sosok yang mendidik, membimbing dan mengasuh anak-anak mereka di sekolah. Masyarakat akan merasakan kehadiran guru karena masyarakatlah yang akan menerima kembali lulusan sekolah setelah mereka dididik dan diajar oleh para guru.

Pada era globalisasi, profesi guru bermakna strategis, karena guru mengemban tugas sejati bagi proses kemanusiaan, pemanusiaan, pencerdasan, pembudayaan, dan pembangun karakter bangsa. Esensi dan eksistensi makna strategis profesi guru diakui dalam realitas sejarah pendidikan di Indonesia. Pengakuan itu memiliki kekuatan formal tatkala tanggal 2 Desember 2004, Presiden Soesilo Bambang Yudhoyono mencanangkan guru sebagai profesi. Satu tahun kemudian, lahirlah Undang-Undang No. 14 Tahun 2005 tentang Guru dan Dosen sebagai dasar legal pengakuan atas profesi guru dengan segala dimensinya.

Harapan-harapan besar muncul pasca lahirnya Undang-Undang No. 14 Tahun 2005 tentang Guru dan Dosen. Di dalam UU ini disebutkan bahwa guru adalah pendidik profesional dengan tugas utama mendidik, mengajar, membimbing, mengarahkan, melatih, menilai, dan mengevaluasi peserta didik pada pendidikan anak usia dini jalur pendidikan formal, pendidikan dasar, dan pendidikan menengah. Guru adalah pendidik profesional yang mempunyai tugas, fungsi, dan peran penting dalam mencerdaskan kehidupan bangsa. Guru profesional mampu berpartisipasi dalam pembangunan nasional untuk mewujudkan insan Indonesia yang bertakwa kepada Tuhan Yang Maha Esa, unggul dalam Ilmu Pengetahuan dan Teknologi (IPTEK), memiliki jiwa estetis, etis, berbudi pekerti luhur, dan berkepribadian.

Masa depan masyarakat, bangsa dan negara, sebagian besar ditentukan oleh guru. Karena itu, profesi guru perlu dikembangkan secara terus menerus dan proporsional menurut jabatan fungsional guru. Agar fungsi dan tugas yang melekat pada jabatan fungsional guru dilaksanakan sesuai dengan aturan yang berlaku, maka diperlukan Penilaian Kinerja Guru (PK Guru) yang menjamin terjadinya proses pembelajaran yang berkualitas di semua jenjang pendidikan.
Pelaksanaan PK Guru dimaksudkan untuk mewujudkan guru yang profesional, karena harkat dan martabat suatu profesi ditentukan oleh kualitas layanan profesi tersebut. Untuk memberi pengakuan bahwa setiap guru adalah seorang profesional dibidangnya dan sebagai penghargaan atas prestasi kerjanya, maka PK Guru harus dilakukan terhadap guru di semua satuan pendidikan formal yang diselenggarakan oleh pemerintah, pemerintah daerah, dan masyarakat. Guru yang dimaksud tidak terbatas pada guru yang bekerja di satuan pendidikan di bawah kewenangan Kementerian Pendidikan dan Kebudayaan, tetapi juga mencakup guru yang bekerja di satuan pendidikan di lingkungan Kementerian Agama.

Rendahnya prestasi siswa umumnya merupakan sesuatu yang sering dipertanyakan terkait dengan tugas utama guru untuk mendidik, mengajar, membimbing dan mengarahkan siswa. Rendahnya daya serap siswa pada Ujian Akhir Nasional, kesemuanya berujung pada pertanyaan tentang bagaimana guru melakukan tugas utamanya, dan bagaimana kinerja guru pada umumnya. Di sisi lain, ilmu pengetahuan dan teknologi (IPTEK), baik sebagai substansi materi ajar maupun piranti penyelenggaraan pembelajaran, terus berkembang. Dinamika ini menuntut guru untuk selalu meningkatkan dan menyesuaikan kompetensinya agar mampu mengembangkan dan menyajikan materi pelajaran yang aktual dengan menggunakan berbagai pendekatan, metode, dan teknologi pembelajaran terkini. Hanya dengan cara itu guru mampu menyelenggarakan pembelajaran yang berhasil mengantarkan peserta didik memasuki dunia kehidupan sesuai dengan kebutuhan dan tantangan pada zamannya. Sebaliknya, ketidakmauan dan ketidakmampuan guru menyesuaikan wawasan dan kompetensi dengan tuntutan perkembangan lingkungan profesinya justru akan menjadi salah satu faktor penghambat ketercapaian tujuan pendidikan dan pembelajaran.

Hingga kini, baik dalam fakta maupun persepsi, masih banyak kalangan yang meragukan kompetensi guru baik dalam bidang studi yang diajarkan maupun bidang lain yang mendukung terutama bidang didaktik dan metodik pembelajaran. Keraguan ini cukup beralasan karena didukung oleh hasil uji kompetensi yang menunjukkan masih banyak guru yang belum mencapai standar kompetensi yang ditetapkan. Pada bulan Februari Tahun 2012, pemerintah melaksanakan ujian kompetensi guru yang diikuti oleh 281.016 guru SD, SMP, SMA, dan 
SMK dari yang telah mendaftar sejumlah 285.884 orang. Secara nasional nilai UKA bagi guru tanpa melihat bidang studi dan jenjang pendidikan memiliki nilai tertinggi 97,0 dan nilai terendah adalah 1,0 dengan nilai rerata (mean) sebesar 42,25.

Inilah yang amat mengejutkan. Dari nilai maksimal 100 , rata-rata secara nasional, guruguru yang mengikuti uji kompetensi ini hanya mampu mencapai nilai 42,25. Ini berarti kompetensi guru masih rendah (Suyanto, 2012, p.2). Sebuah studi yang dilakukan oleh Kemendikbud RI juga menyimpulkan bahwa pembelajaran di kelas lebih didominasi oleh ceramah satu arah dari guru dan sangat jarang terjadi tanya jawab. Ini mencerminkan betapa masih banyak guru yang tidak berusaha meningkatkan dan memutakhirkan profesionalitasnya (Kemendikbud, 2012, p.16).

Reformasi pendidikan yang diamanatkan oleh Undang-Undang Nomor 20 tahun 2003 tentang Sistem Pendidikan Nasional, Undang Undang No 14 Tahun 2005 tentang Guru dan Dosen, dan Peraturan Pemerintah Nomor 19 Tahun 2005 tentang Standar Nasional Pendidikan menuntut reformasi guru untuk memiliki tingkat kompetensi guru yang lebih tinggi, baik kompetensi pedagogik, kepribadian, profesional, maupun sosial. Akibat dari masih banyaknya guru yang tidak menguasai kompetensi yang dipersyaratkan, ditambah dengan kurangnya kemampuan untuk menggunakan TIK, membawa dampak pada siswa paling tidak dalam dua hal.

Pertama, siswa hanya terbekali dengan kompetensi yang sudah usang. Akibatnya, produk sistem pendidikan dan pembelajaran tidak siap terjun ke dunia kehidupan nyata yang terus berubah. Kedua, pembelajaran yang diselenggarakan oleh guru juga kurang kondusif bagi tercapainya tujuan secara aktif, kreatif, efektif, dan menyenangkan karena tidak didukung oleh penggunaan teknologi pembelajaran yang modern dan handal. Hal itu didasarkan pada kenyataan bahwa substansi materi pelajaran yang harus dipelajari oleh anak didik terus berkembang baik volume maupun kompleksitasnya (Kemendikbud, 2012, pp.16-17).

Dengan mencermati kembali UndangUndang RI No. 14 Tahun 2005 tentang Guru dan Dosen yang telah disahkan oleh pemerintah pada tanggal 30 Desember 2005, terdapat poin penting yang merupakan salah satu unsur yang amatlah didambakan oleh para guru. Poin itu adalah bahwa guru di semua jenjang diakui sebagai tenaga profesional dan pengakuan itu harus dibuktikan dengan sertifikat pendidik (UU Guru dan Dosen, 2005, p.4).

Guru menyambut dengan gembira lahirnya undang-undang itu karena pengakuan profesi guru oleh pemerintah mengisyaratkan bahwa jabatan guru telah ditempatkan oleh undangundang itu sebagai suatu profesi, setara dengan profesi dokter, pengacara, akuntan atau yang lainnya. Diharapkan, dengan undang-undang ini, harkat dan martabat guru akan terangkat.

Beberapa pasal yang ada di dalam undang-undang itu juga memberikan statement yang amat memihak bagi masa depan guru, khususnya pasal-pasal yang berkaitan dengan hakhak guru. Secara psikologis, guru berada di wilayah yang aman untuk urusan kesejahteraan hidup. Perhatikan pasal 14 ayat 1. Di pasal ini disebutkan bahwa guru memperoleh penghasilan di atas kebutuhan hidup minimum dan mendapatkan jaminan kesejahteraan sosial. Kemudian statement ini dipertegas lagi di pasal 15 , bahwa yang dimaksud dengan penghasilan di atas kebutuhan hidup minimum meliputi gaji pokok, tunjangan yang melekat pada gaji, tunjangan khusus, dan maslahat tambahan yang terkait dengan tugas sebagai guru yang ditetapkan dengan prinsip penghargaan atas prestasi (UU Guru dan Dosen, 2005, pp.7-8).

Selain itu, pada pasal-pasal berikutnya guru akan diberi tunjangan profesi dan tunjangan khusus (bagi guru yang bertugas di daerah khusus). Bahkan di pasal 19 secara eksplisit diuraikan mengenai maslahat tambahan berupa berbagai kesejahteraan yang diperoleh dalam bentuk tunjangan pendidikan, asuransi pendidikan, beasiswa, dan kemudahan untuk memperoleh pendidikan bagi putra dan putri guru, serta layanan kesehatan (UU Guru dan Dosen, 2005, p.10)

Jaminan kemudahan memperoleh kesempatan pendidikan bagi para putra-putri guru ditegaskan dalam penjelasan Pasal 19, yaitu: "Yang dimaksud dengan kemudahan untuk memperoleh pendidikan bagi putra-putri guru adalah berupa kesempatan dan keringanan biaya pendidikan bagi putra-putri guru yang telah memenuhi syarat-syarat akademik untuk menempuh pendidikan dalam satuan pendidkan tertentu." (UU Guru dan Dosen, 2005, p.9)

Statement mengenai jaminan kemudahan memperoleh pendidikan bagi para putra-putri guru ini juga amat positif. Pengamatan secara sekilas akan dapat ditemukan bahwa tidak jarang dijumpai putra-putri seorang guru yang telah berjasa membawa anak-anak orang lain 
bisa membaca, menulis, berhitung, kemudian berkembang dan menjadi insinyur, dokter, ahli hukum, arstitek, advokat, dan lain-lainnya, tetapi anak-anak guru sendiri terkadang gagal mendapat tempat terhormat untuk melanjutkan sekolah/pendidikan ke jenjang yang lebih tinggi atau gagal masuk ke fakultas atau jurusan-jurusan favorit yang porspektif. Kegagalan itu bukan karena anak-anak guru dari segi intelektual tidak mampu, tetapi boleh jadi sistem seleksi penerimaan siswa atau mahasiswa baru "hanya" memberikan peluang yang luas bagi golongan yang kuat secara finansial.

Dengan berbagai fasilitas yang telah diamanatkan oleh undang-undang tentang guru dan dosen, diharapkan guru akan lebih tenang dalam bekerja, harkat dan martabat mereka akan terangkat dan guru akan mendapatkan kepuasan kerja secara maksimal. Namun demikian, apa yang terjadi di lapangan masih jauh dari hal yang ideal. Menurut Ketua Badan Pengembangan Sumber Daya Manusia Pendidikan dan Penjaminan Mutu Pendidikan, Syawal Gultom, secara umum, kualitas guru dan kompetensi guru di Indonesia masih belum sesuai dengan yang diharapkan. Dari sisi kualifikasi pendidikan, hingga saat ini, dari 2,92 juta guru, baru sekitar 51 persen yang berpendidikan S-1 atau lebih, sedangkan sisanya belum berpendidikan S-1. Begitu pun dari persyaratan sertifikasi, hanya 2,06 juta guru atau sekitar 70,5 persen guru yang memenuhi syarat sertifikasi. Adapun 861.671 guru lainnya belum memenuhi syarat sertifikasi, yakni sertifikat yang menunjukkan guru tersebut profesional. Selain jenjang pendidikan yang belum memadai, kompetensi guru juga masih bermasalah. Saat dilakukan tes terhadap guru semua bidang studi, rata-rata tak sampai 50 persen soal yang bisa dikerjakan. Tidak ada guru yang meraih nilai 80 . Bahkan, ada guru yang meraih nilai terendah, 1 (www.kompas.com, 7 Maret 2012, diakses tanggal 4 Oktober 2012).

Dalam sebuah diskusi Forum Kebijakan Anggaran Pendidikan yang pernah diselenggarakan di Jakarta, peserta diskusi mengingatkan pemerintah agar guru harus dilihat sebagai ujung tombak atau bagian paling penting dalam peningkatan kualitas pendidikan. Forum ini, antara lain, beranggotakan mantan anggota Komisi X DPR, seperti Didik J Rachbini, Musfihin Dahlan, M Yasin Kara, Heri Akhmadi, dan mantan Ketua Umum Asosiasi Perguruan Tinggi Swasta Indonesia Suharyadi, serta sejumlah praktisi pendidikan. Dalam diskusi itu, Heri
Akhmadi mengatakan bahwa pada tahun 2011, 56 persen anggaran pendidikan digunakan untuk gaji dan tunjangan guru, dan setiap tahun, anggaran itu dipastikan terus meningkat. Guru semakin sejahtera, namun, menurut Suharyadi, kualitas atau peningkatan mutu guru masih sangat tertinggal (www.kompas.com, 7 Maret 2012, diakses tanggal 4 Oktober 2012)

Melihat secara sekilas kondisi guru di Indonesia, amat tepat kiranya jika merefleksikan kondisi guru di Indonesia tersebut dengan prestasi siswa Indonesia secara umum. Terkait dengan prestasi siswa Indonesia, khususnya dalam bidang Matematika, data-data dari PISA (Programme for International Student Assesment), sebuah lembaga internasional yang memfokuskan diri meneliti literasi matematika, sains dan membaca pada siswa-siswa di seluruh dunia, masih amat layak untuk dijadikan patokan. Prestasi siswa Indonesia yang dimuat didalam International Report PISA masih belum menggembirakan.

Meskipun sampai awal bulan Januari 2013 hasil dari PISA yang diselenggarakan pada tahun 2012 belum dirilis oleh penyelenggara PISA, hasil-hasil PISA pada tahun-tahun sebelumnya dapat dijadikan tolok ukur mengenai pencapaian siswa Indonesia khususnya di bidang Matematika. Pada penyelenggaraan PISA tahun 2009, poin rata-rata siswa Indonesia adalah 371, masih lebih rendah dari Singapura, yakni 562, atau Thailand, 419. (OECD, 2010, p.15). Poin ini tidak terlalu jauh berbeda dengan poin yang didapatkan siswa Indonesia 9 tahun sebelumnya, yakni pada tahun 2000. Pada PISA yang diselenggarakan tahun 2000, literasi matematika siswa Indonesia memiliki rata-rata poin 367 , lebih rendah dari Thailand (432) dan Jepang (557). Poin 367, adalah poin terendah dimana siswa hanya bisa menyelesaikan satu langkah pengerjaan soal matematika yang sederhana. Siswa dengan skor tersebut belum mencapai ranah penalaran, generalisasi ataupun melakukan proses kognitif tingkat tinggi. (OECD, 2000, p.100).

Selanjutnya, pada PISA yang diselenggarakan pada tahun 2003, literasi matematika siswa Indonesia juga terhitung masih lemah. Sekitar 50 persen siswa Indonesia hanya sanggup menyelesaikan soal-soal matematika pada level 1 yang terdiri dari pertanyaan rutin biasa, dan hanya kurang dari 2 persen yang sanggup meraih level 6 dimana penalaran merupakan salah satu parameter utama di level ini (OECD, 2003, p.8). Pada PISA yang diselenggarakan 
pada tahun 2006, literasi matematika siswa Indonesia juga masih terbilang kurang memuaskan. Pada tahun 2006, 35,2 persen siswa Indonesia mempunyai literasi matematika level 1 , sementara tidak ada satu pun ( 0 persen) yang memiliki literasi matematika level 6 (OECD, 2006, p.T6.2a).

Rendahnya prestasi siswa Indonesia, khususnya di bidang matematika, tentu tidak bisa dilepaskan begitu saja dari faktor guru. Faktor guru dalam proses pembelajaran masih amat signifikan. Seorang anggota Komisi X Dewan Perwakilan Rakyat (DPR) RI dari Fraksi PKS, Rohmani, pernah mengemukakan pendapatnya mengenai hal ini dalam Rapat Dengar Pendapat Umum (RDPU) antara Komisi X DPR dan Asosiasi Lembaga Perguruan Tinggi Kependidikan Indonesia (ALPTKI) di Gedung DPR RI, Selasa tanggal 29 Maret 2011 lalu. Dalam rapat tersebut mengemuka pembahasan bahwa kualitas guru tetap menjadi persoalan mendasar dalam dunia pendidikan di tanah air. "Sejauh ini kualitas guru masih rendah bila dibandingkan dengan negara tetangga seperti Malaysia dan Singapura. Ironisnya, perhatian terhadap kualitas guru masih minim karena memperbaiki kualitas guru sama dengan mengatasi tujuh puluh persen persoalan pendidikan nasional," ujar Rohmani (www.kompas.com tanggal 31 Maret 2011, diakses tanggal 4 Oktober 2012).

Guru yang telah mendapatkan pengakuan dari pemerintah sebagai tenaga profesi melalui UU Guru dan Dosen, seharusnya memiliki kompetensi sesuai yang diharapkan. Demikian pula dengan berbagai macam hak dan fasilitas yang diterima guru yang telah dijamin undang-undang, seharusnya dapat meningkatkan kinerja dan kepuasan kerja mereka sebagai guru. Jika ini tidak terjadi, maka komitmen profesional guru belum tumbuh secara maksimal di kalangan guru. Dari berbagai fakta tersebut, penelitian ini perlu dilakukan.

Mencermati uraian di atas, terdapat beberapa masalah yang perlu dicermati dalam penelitian ini, diantaranya adalah: (1) kinerja guru, khususnya guru matematika dianggap masih kurang memuaskan, (2) baik dalam fakta maupun persepsi, masih banyak kalangan yang meragukan kompetensi guru khususnya guru matematika, (3) semangat mengajar guru matematika telah meningkat, tetapi komitmen untuk lebih meningkatkan profesionalitas mereka masih kurang, (4) kepuasan kerja guru, khususnya guru matematika belum dapat teridentifikasi dengan baik, (5) komitmen profesional guru matematika yang merupakan unsur penting yang dapat memicu keinginan guru matematika untuk terus meningkatkan dan memutakhirkan profesionalitasnya belum dapat mempengaruhi kinerja dan kepuasan kerja mereka, dan (6) kompetensi guru matematika belum mempengaruhi kinerja mereka secara maksimal. Dari cakupan masalah yang sedemikian luas, penelitian ini akan dibatasi dan hanya difokuskan untuk mendeskripsikan dan menganalisis pengaruh kompetensi guru terhadap komitmen profesional, serta dampaknya pada kinerja dan kepuasan kerja guru matematika SMP (Sekolah Menengah Pertama) dan MTs (Madrasah Tsanawiyah)

Adapun tujuan dari penelitian ini adalah mendeskripsikan pengaruh kompetensi terhadap komitmen profesional guru matematika SMP dan MTs, mendeskripsikan pengaruh kompetensi terhadap kinerja guru matematika SMP dan MTs, mendeskripsikan pengaruh komitmen profesional terhadap kinerja guru matematika SMP dan MTs serta mendeskripsikan pengaruh komitmen profesional terhadap kepuasan kerja guru Matematika SMP dan MTs.

\section{METODE}

\section{Jenis Penelitian}

Dilihat dari metode penelitian yang digunakan, penelitian ini menggunakan metode ex post facto, dimana peneliti melakukan penelitian dengan menggunakan data berdasarkan fakta yang telah terjadi. Sementara itu, berdasarkan jenis data dan teknik analisisnya, penelitian ini termasuk penelitian yang menggunakan pendekatan kuantitatif, karena analisis pada penelitian ini menggunakan data numerik (angka) yang diolah dengan metode statistik. Desain penelitian ini adalah penelitian korelasional yaitu menjelaskan hubungan kausalitas yang terjadi di antara variabel-variabel penelitian melalui pengujian hipotesis. Hipotesis yang telah disusun digambarkan dalam sebuah model struktural yang menghubungkan variabel-variabel yang diteliti, yaitu variabel kompetensi guru, komitmen profesional, kinerja dan kepuasan kerja guru matematika.

\section{Waktu dan Tempat Penelitian}

Penelitian dilaksanakan dari tanggal 2 Mei 2013 sampai dengan tanggal 10 Juni 2013 di Sekolah Menengah Pertama (SMP) dan Madrasah Tsanawiyah (MTs) di Kabupaten Ponorogo. 


\section{Target/Subjek Penelitian}

Populasi penelitian ini adalah semua guru matematika yang bekerja di Sekolah Menengah Pertama (SMP) dan Madrasah Tsanawiyah (MTs) di Kabupaten Ponorogo sebanyak 262 orang. Dari populasi penelitian sebanyak 262 orang, terpilih 82 orang guru matematika sebagai sampel. Pengambilan sampel dari populasi ini menggunakan teknik two stage cluster random sampling. Cluster 1 adalah cluster kecamatan. Dari 21 kecamatan yang ada di Kabupaten Ponorogo, terpilih secara acak 4 cluster kecamatan, yaitu Kecamatan Balong, Kecamatan Jenangan, Kecamatan Ponorogo dan Kecamatan Jetis. Cluster 2 adalah cluster sekolah SMP dan MTs sebanyak 15 cluster. Dari keseluruhan sekolah tersebut, terambil secara acak 82 orang guru matematika.

\section{Prosedur Penelitian}

Penelitian dilakukan dengan cara melakukan observasi kinerja, melakukan penilaian terhadap kompetensi guru, dan menyebarkan kuesioner kepada guru matematika yang terpilih menjadi sampel. Observasi dilakukan oleh peer (teman sejawat guru) bersama dengan peneliti. Observasi dilakukan untuk mendapatkan data kinerja guru matematika di dalam kelas. Hasil observasi ini dituangkan ke dalam lembar observasi. Penilaian terhadap aspek-aspek kompetensi guru matematika dilakukan oleh peer (teman sejawat guru) bersama dengan peneliti. Hasil penilaian ini dituangkan ke dalam lembar penilaian. Kuesioner yang telah diisi, merupakan data komitmen profesional dan kepuasan kerja. Selanjutnya, tabulasi dilakukan terhadap keseluruhan data dan data-data tersebut diolah dengan aplikasi komputer SPSS ver. 17 dan AMOS ver. 18.

\section{Data, Intrumen, dan Teknik Pengumpulan Data}

Data yang dikumpulkan dalam penelitian ini berasal dari sumber data primer dan sumber data sekunder. Sumber data primer adalah guru, sedangkan sumber data sekunder adalah peer atau teman sejawat guru dan dokumen-dokumen yang terkait.

Banyaknya instrumen yang digunakan dalam penelitian ini ada 4. Untuk mengukur komitmen profesional dan kepuasan kerja, akan digunakan instrumen penelitian berupa kuesioner yang diisi secara langsung oleh guru matematika. Kuesioner yang digunakan berbentuk daftar cocok (check list) yang berisi pernyataanpernyataan sesuai dengan variabel yang akan diukur. Model skala yang digunakan adalah skala Likert. Data mengenai kompetensi guru yang merefleksikan kompetensi profesional, kompetensi pedagogis, kompetensi kepribadian dan kompetensi sosial guru matematika diperoleh melalui instrumen lembar penilaian. Data kinerja guru matematika diperoleh melalui lembar observasi. Lembar observasi kinerja guru matematika diisi oleh peer (teman sejawat guru) bersama-sama dengan peneliti, lembar penilaian yang merefleksikan kompetensi profesional dan kompetensi pedagogis diisi oleh guru matematika dan dikonfirmasi oleh peer (teman sejawat guru) dan peneliti, sedangkan lembar penilaian untuk kompetensi kepribadian dan kompetensi sosial langsung diisi oleh peer (teman sejawat guru).

Teknik pengumpulan data pada penelitian ini adalah dengan menggunakan kuesioner, lembar penilaian, dan lembar observasi. Kuesioner digunakan untuk mengumpulkan data komitmen profesional dan kepuasan kerja guru matematika. Lembar penilaian digunakan untuk mengumpulkan data kompetensi guru yang merefleksikan kompetensi profesional, kompetensi pedagogis, kompetensi kepribadian dan kompetensi sosial. Lembar observasi digunakan untuk mengumpulkan data kinerja guru matematika.

Dalam penelitian ini, instrumen yang digunakan adalah instrumen non tes, sehingga diperlukan validitas isi (content validity) dan validitas konstruk (construct validity). Bukti validitas isi (content validity) dari keseluruhan instrumen non tes di dalam penelitian ini didapatkan dengan meminta pertimbangan para ahli (expert judgement), yaitu ibu Dr. Dhoriva Urwatul Wutsqa dan ibu Dr. Heri Retnawati dari Program Pascasarjana Universitas Negeri Yogyakarta (UNY) Program Studi Pendidikan Matematika. Bukti validitas isi yang dihasilkan merupakan penilaian terhadap kesesuaian antara item-item atau indikator-indikator instrumen dengan definisi konstruk/variabel. Bukti validitas konstruk (construct validity) didapatkan melalui Confirmatory Factor Analysis (CFA). $C F A$ digunakan untuk mengukur validitas konstruk karena $C F A$ memberikan bukti secara kuantitatif bagaimana skor-skor instrumen teramati merepresentasikan variabel laten/konstruk yang didesain untuk diukur. Dengan menggunakan $C F A$, akan dilihat validitas konstruk yang terdiri dari komponen-komponen convergent validity dan discriminant validity. Suatu variabel yang 
dianalisis dengan menggunakan CFA dikatakan mempunyai validitas yang baik apabila nilai standardized loading factor-nya lebih besar atau sama dengan 0,50 dan lebih ideal jika lebih besar dari 0,70 (Pashwan, 2009, p.36). Nilai tersebut merupakan bukti adanya convergent validity. Dalam mengukur convergent validity, diperlukan satu pengukuran lagi yaitu $A V E$ atau Average Variance Extracted.

Nilai $A V E$ yang lebih besar atau sama dengan 0,50 merupakan indikasi convergent validity yang baik, sedangkan jika nilai $A V E$ yang kurang dari 0,50 mengindikasikan bahwa secara rata-rata ada lebih banyak error yang terdapat dalam item-item indikator daripada variance yang dapat dijelaskan oleh konstruk laten/faktor di mana konstruk laten/faktor tersebut terdesain untuk diukur (Pashwan, 2009, p.36). Selain convergent validity, bukti validitas konstruk yang lain adalah discriminant validity. Discriminant Validity ditujukan untuk mengevaluasi apakah sebuah konstruk benar-benar berbeda dari konstruk lainnya, atau unidimensional. Artinya, indikator-indikator dari sebuah konstruk hanya me-loading pada konstruknya dan tidak cross-loading pada konstruk yang lain.

$C F A$ juga dapat digunakan untuk menguji reliabilitas konstruk. Uji reliabilitas ini dilakukan untuk membuktikan konsistensi dan keajegan serta ketepatan dan akurasi instrumen dalam mengukur suatu konstruk. Untuk mengukur reliabilitas suatu konstruk, digunakan sebuah formula yaitu formula untuk menghitung Construct Reliability. Dalam beberapa literatur, reliabilitas konstruk dikatakan baik jika memenuhi nilai construct reliability lebih besar atau sama dengan 0,70 (Pashwan, 2009, p.36).

\section{Teknik Analisis Data}

Analisis data dalam penelitian ini meliputi analisis deskriptif, uji asumsi dan analisis secara statistik dengan menggunakan Structural Equation Modeling (SEM).

\section{Analisis Deskriptif}

Analisis deskriptif dilakukan terhadap variabel-variabel penelitian, baik variabel eksogen maupun variabel endogen. Dalam penelitian ini, analisis deskriptif meliputi ukuran tendensi sentral dan dispersi. Ukuran tendensi sentral yang digunakan adalah rata-rata, sedangkan ukuran dispersi yang digunakan adalah standar deviasi, skor minimal dan skor maksimal. Variabel-variabel yang dideskripsikan adalah kompetensi, komitmen profesional, kinerja dan kepuas- an kerja guru matematika. Keseluruhan data yang diperoleh dianalisis dengan statistik deskriptif. Analisis deskriptif dilakukan untuk memperoleh skor keempat variabel tersebut. Skor-skor tersebut digolongkan melalui pembagian wilayah di bawah lengkungan kurva normal menjadi 5 daerah yang masing-masing menunjukkan kualifikasi A (sangat tinggi), B (tinggi), C (sedang), D (rendah) dan E (sangat rendah).

\section{Uji Asumsi}

Uji asumsi meliputi ukuran sampel, uji normalitas, uji keberadaan pencilan dan uji singularitas. Dalam penelitian ini, ukuran sampel adalah 82. Dengan rasio $\mathrm{N}: \mathrm{q}=5: 1$, di mana $\mathrm{N}$ adalah ukuran sampel dan $\mathrm{q}$ adalah banyaknya parameter yang diestimasi, maka ukuran sampel ini sudah layak untuk digunakan dengan catatan bahwa data harus berasal dari populasi yang berdistribusi normal. Pada taraf signifikansi $\alpha=0,01$, keseluruhan nilai skewness dan kurtosis dari variabel teramati (observed variable) yang diuji secara statistik dengan distribusi $z$, mencerminkan bahwa data berasal dari populasi yang berdistribusi normal. Nilai skewness terendah adalah 0,70 pada variabel Komit1 dan nilai skewness tertinggi adalah 0,448 pada variabel Kine1. Nilai kurtosis terendah adalah 0,121 pada variabel Komp1 dan nilai kurtosis tertinggi adalah 0,744 pada variabel Kine2. Pada taraf signifikansi $\alpha=0,01$, nilai multivariate kurtosis adalah sebesar 1,084 dengan nilai kritis 0,388 . Secara keseluruhan, nilai-nilai skewness dan kurtosis yang diuji secara statistik dengan distribusi $z$, pada taraf signifikansi $\alpha=0,01$, menunjukkan bahwa data penelitian ini berasal dari populasi yang berdistribusi normal.

Untuk mengetahui apakah terdapat multivariate outlier di dalam data, digunakan uji statistik melalui jarak Mahalanobis (Mahalanobis distance). Mahalanobis Distance tertinggi adalah 20,053. Nilai ini masih berada dibawah nilai distribusi Chi Square ( $\chi 2)$ pada level $\mathrm{p}<0,001$ dan derajat kebebasan 8 , yakni sebesar 26,124. Dengan demikian, tidak ditemukan multivariate outlier pada data penelitian ini. Uji singularitas diketahui dengan melihat nilai determinan dari sample covariance matrix. Nilai determinan dari sample covariance matrix adalah 449228030,355 yang berada jauh diatas 0 . Artinya, sample covariance matrix bukanlah matriks singular, sehingga data penelitian layak untuk diestimasi dan dianalisis memakai 
Structural Equation Modeling (SEM). Semua nilai eigen juga lebih besar dari 0 sehingga matriks data memenuhi kategori Positive Definite.

\section{Analisis Statistik dengan Structural Equation Modeling (SEM)}

Analisis dilakukan sesuai dengan model tahapan proses yang dikemukakan oleh Bollen dan Long (Hengky Latan, 2012, p.42). Analisis dimulai dengan menyusun sebuah hubungan antar variabel (spesifikasi model) melalui diagram alur (path diagram) yang akan memudahkan peneliti dalam melihat hubungan-hubungan kausalitas yang ingin diuji. Untuk mengembangkan path diagram, digunakan perangkat lunak (software) pendukung yaitu AMOS 18. Dengan program tersebut, diagram alur yang telah dikembangkan dapat langsung dikonversi menjadi persamaan dan diestimasi.

Langkah berikutnya adalah melakukan identifikasi model. Dalam SEM, persoalan identifikasi model amatlah penting untuk mengetahui apakah model yang dibangun dengan data empiris yang dikumpulkan di lapangan memiliki nilai yang unik ataukah tidak. Jika model tidak memiliki nilai yang unik, maka model tersebut tidak dapat diidentifikasi (unidentified). Penyebabnya adalah informasi yang terdapat pada data empiris tidak cukup untuk menghasilkan solusi yang unik dalam menghitung parameter estimasi model.

Langkah selanjutnya adalah melakukan estimasi model. Didalam SEM, terdapat setidaknya tiga pilihan metode estimasi yang sering digunakan oleh peneliti yaitu Maximum Likelihood (ML), Generalized Least Squares (GLS), dan Asymptotically Distribution Free (ADF). Maximum Likelihood merupakan metode estimasi yang paling populer dan banyak digunakan oleh peneliti di bidang SEM. Metode Maximum Likelihood (ML) akan menghasilkan estimasi parameter yang terbaik (unbiased) apabila data yang digunakan memenuhi asumsi multivariate normality dan akan menjadi bias apabila asumsi ini tidak dipenuhi. Kelemahan metode ML adalah jika ukuran sampel yang digunakan untuk estimasi model lebih besar dari 400, maka metode ini akan sangat sensitif dan menghasilkan kesesuaian (goodness of fit) yang buruk. Dalam penelitian ini, estimasi yang digunakan adalah estimasi dengan menggunakan metode Maximum Likelihood (ML).

Langkah analisis selanjutnya adalah evaluasi model. Evaluasi model bertujuan untuk mengevaluasi model secara keseluruhan apakah model memiliki kecocokan atau tidak dengan data empiris. Evaluasi model dalam SEM dapat dilakukan dengan melihat nilai-nilai hasil pengukuran (measurement model) melalui analisis faktor konfirmatori (confirmatory factor analysis), kemudian dilanjutkan dengan evaluasi model struktural (structural model) secara keseluruhan dengan menilai kelayakan model melalui kriteria goodness of fit. Analisis terakhir adalah respesifikasi model. Setelah melakukan penilaian goodness of fit dan jika didapatkan model yang diuji ternyata tidak fit, baik secara keseluruhan (overall) maupun secara individual (di dalam parameter yang diestimasi), maka perlu dilakukan respesifikasi model.

\section{HASIL DAN PEMBAHASAN}

Model struktural diajukan untuk menguji hipotesis penelitian. Model struktural menggambarkan hubungan 4 variabel laten, yaitu: kompetensi guru, komitmen profesional, kinerja dan kepuasan kerja guru matematika. Variabel laten kompetensi direpresentasikan oleh dua variabel manifes yaitu Komp1 dan Komp2. Variabel laten komitmen profesional direpresentasikan oleh dua variabel manifes Komit1 dan Komit2. Variabel laten kinerja direpresentasikan oleh dua variabel manifes yaitu Kine1 dan Kine2. Variabel laten kepuasan kerja direpresentasikan oleh dua variabel manifes Int dan Ext. Model tersebut dapat digambarkan sebagaimana Gambar 1 berikut ini: 


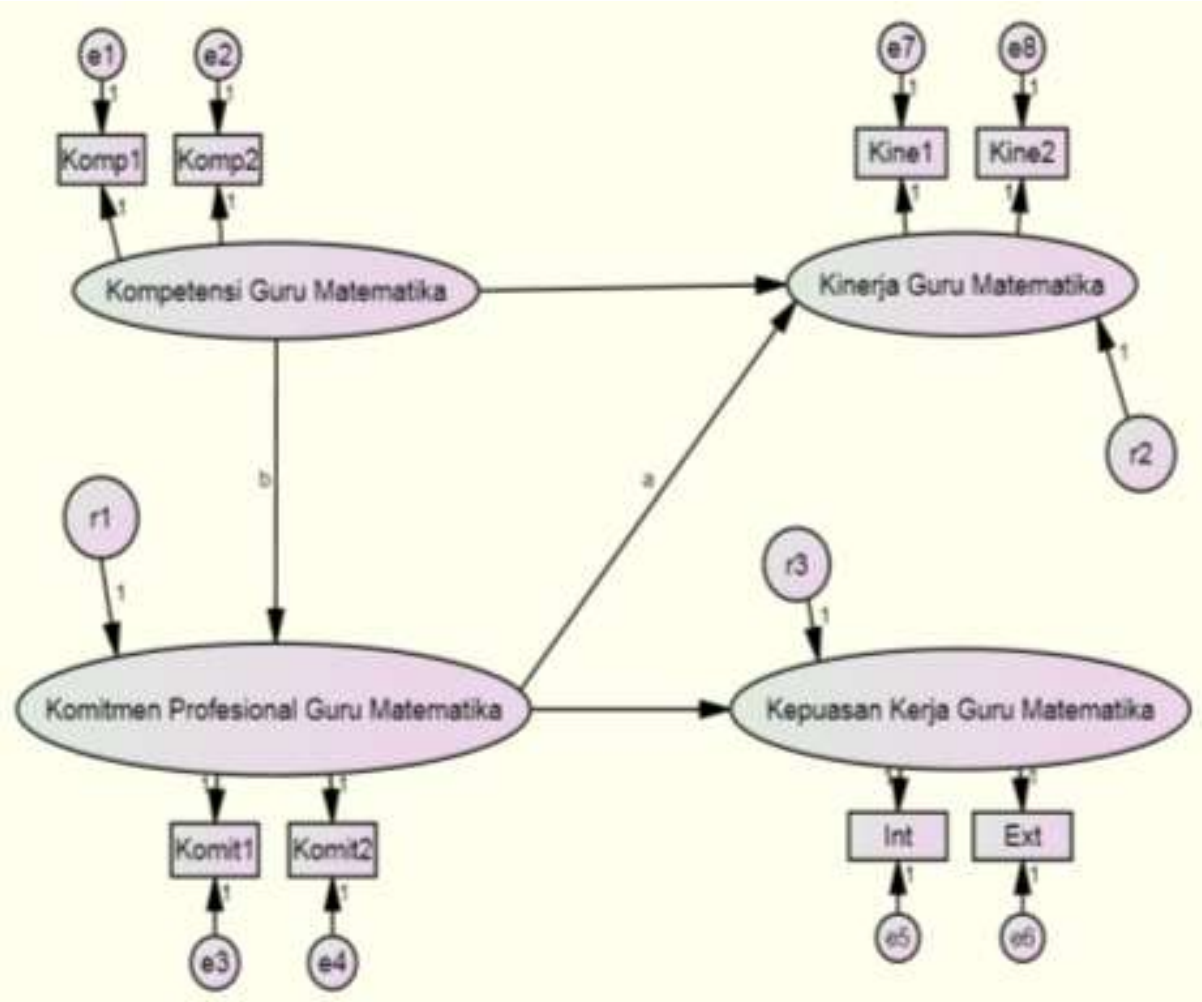

Gambar 1. Model Struktural yang Menggambarkan Keterkaitan Antar Variabel untuk Menguji Hipotesis Penelitian

Dari Gambar 1 dapat dijelaskan bahwa parameter yang bersifat fixed (tidak diestimasi) ada 19, yaitu: 8 error weights, 8 regression weights dan 3 residual weights. Parameter yang diestimasi sebanyak 16, yaitu 4 regression weights dan 12 variances. Banyaknya parameter unik (distinct parameters) yang diestimasi sebanyak 15 sedangkan banyaknya unsur sample covariance matrix adalah $(8 \times 9) / 2=36$, sehingga model ini mempunyai derajat kebebasan (degree of freedom) sebanyak $36-15=21$.

Model diatas dapat diidentifikasi dengan status overidentified. Dengan parameter yang diestimasi sebanyak 15 buah, model diatas mempunyai derajat kebebasan $36-15=21$. Nilai Chi Square $(\chi 2)$ dari model diatas adalah 30,223 dengan level probabilitas $0,088(\geq 0,05)$. Nilai ini menunjukkan bahwa $\mathrm{H}_{0}$ yang menyatakan bahwa tidak ada perbedaan antara sample covariance matrix $(\Sigma)$ dengan implied covariance matrix $\left(\sum(\theta)\right)$ tidak dapat ditolak, sehingga model ini secara keseluruhan adalah fit dan dapat diterima. Indeks kesesuaian model selengkapnya dapat dilihat pada tabel berikut ini:

Tabel 1.Nilai Keluaran Uji Kecocokan Model untuk Model Struktural

\begin{tabular}{cccc}
\hline $\begin{array}{c}\text { Goodness of Fit } \\
\text { Index }\end{array}$ & $\begin{array}{c}\text { Cut off } \\
\text { Value }\end{array}$ & Output & Keterangan \\
\hline $\begin{array}{c}\text { Probabilitas Chi } \\
\text { Square }\end{array}$ & $\geq 0,05$ & 0,088 & Fit \\
GFI & $\geq 0,90$ & 0,916 & Fit \\
AGFI & $\geq 0,90$ & 0,856 & Marginal Fit \\
NFI & $\geq 0,90$ & 0,925 & Fit \\
RFI & $\geq 0,90$ & 0,900 & Fit \\
IFI & $\geq 0,90$ & 0,976 & Fit \\
TLI & $\geq 0,90$ & 0,967 & Fit \\
CFI & $\geq 0,90$ & 0,976 & Fit \\
RMSEA & $\leq 0,08$ & 0,074 & Fit \\
CMIN/DF & $\leq 2,00$ & 1,439 & Fit \\
\hline
\end{tabular}

Dari Tabel 1, terlihat bahwa hampir keseluruhan uji kelayakan model untuk Model Struktural dalam kondisi cocok (fit) kecuali AGFI yang berada pada posisi Marginal Fit. Sementara itu, output Regression Weight dari AMOS 18 untuk Model Struktural dapat dilihat dalam tabel berikut ini: 
Tabel 2. Estimasi Regression Weights dari Model Struktural

\begin{tabular}{ccccccc}
\hline & & & Estimate & S.E. & C.R. & P \\
\hline Komitmen & $<---$ & Kompetensi &, 159 &, 069 & 2,321 &, 020 \\
Kinerja & $<---$ & Kompetensi &, 636 &, 159 & 3,999 & $* * *$ \\
Kinerja & $<---$ & Komitmen &, 159 &, 069 & 2,321 &, 020 \\
Kepuasan & $<---$ & Komitmen &, 378 &, 158 & 2,389 &, 017 \\
Ext & $<--$ & Kepuasan & 1,000 & & & \\
Int & $<---$ & Kepuasan & 1,000 & & \\
Komp1 & $<--$ & Kompetensi & 1,000 & & \\
Komp2 & $<---$ & Kompetensi & 1,000 & & \\
Kine1 & $<--$ & Kinerja & 1,000 & & \\
Kine2 & $<---$ & Kinerja & 1,000 & & & \\
Komit2 & $<---$ & Komitmen & 1,000 & & & \\
Komit1 & $<---$ & Komitmen & 1,000 & & & \\
\hline
\end{tabular}

Dari Tabel 2, terlihat bahwa keseluruhan tingkat signifikansi hubungan antar konstruk laten yang dihipotesiskan adalah signifikan, yang ditandai dengan nilai probabilitas $(\mathrm{P})$ yang lebih kecil dari 0,05 . Hipotesis $1\left(\mathrm{H}_{1}\right)$ yang menyatakan bahwa "Terdapat pengaruh positif kompetensi terhadap komitmen profesional guru matematika SMP dan MTs di Kabupaten Ponorogo" tidak dapat ditolak secara signifikan, pada level 0,05, dengan nilai kritis (critical ratio) sebesar 2,321. Pada kolom estimasi juga dapat dijelaskan bahwa ketika kompetensi naik 1 tingkat, maka komitmen profesional mengalami kenaikan 0,159. Kesimpulannya, $\mathrm{H}_{1}$ diterima. Hipotesis $2\left(\mathrm{H}_{2}\right)$ yang menyatakan bahwa "Terdapat pengaruh positif kompetensi terhadap kinerja guru matematika SMP dan MTs di Kabupaten Ponorogo." tidak dapat ditolak secara signifikan pada level 0,001 dengan nilai kritis (critical ratio) sebesar 3,999. Pada kolom estimasi juga dijelaskan bahwa ketika kompetensi naik 1 tingkat, maka kinerja akan naik sebesar 0,636 . Kesimpulannya $\mathrm{H}_{2}$ diterima. Lebih lanjut, Hipotesis $3\left(\mathrm{H}_{3}\right)$ yang menyatakan bahwa "Terdapat pengaruh positif komitmen profesional terhadap kinerja guru matematika SMP dan MTs di Kabupaten Ponorogo." dinyatakan tidak dapat ditolak secara signifikan, pada level 0,05, dengan nilai kritis (critical ratio) sebesar 2,321. Pada kolom estimasi juga dapat dijelaskan bahwa ketika komitmen profesional naik 1 tingkat, maka kinerja mengalami kenaikan 0,159. Kesimpulannya, $\mathrm{H}_{3}$ diterima. Yang terakhir, Hipotesis $4\left(\mathrm{H}_{4}\right)$ yang menyatakan bahwa "Terdapat pengaruh positif komitmen profesional terhadap kepuasan kerja guru matematika SMP dan MTs di Kabupaten Ponorogo." tidak dapat ditolak secara signifikan, pada level 0,05 , dengan nilai kritis (critical ratio) sebesar 2,389. Pada kolom estimasi juga dapat dijelaskan bahwa ketika komitmen profesional naik 1 tingkat, maka kepuasan kerja mengalami kenaikan 0,378. Kesimpulannya, $\mathrm{H}_{4}$ diterima. Ringkasan uji hipotesis selengkapnya dapat dilihat pada tabel berikut ini :

Tabel 3.Ringkasan Uji Hipotesis

\begin{tabular}{|c|c|c|}
\hline & Hipotesis & $\begin{array}{c}\text { Hasil } \\
\text { Pengujian }\end{array}$ \\
\hline $\mathrm{H}_{1}$ & $\begin{array}{l}\text { Terdapat pengaruh positif } \\
\text { kompetensi terhadap komitmen } \\
\text { profesional guru matematika SMP } \\
\text { dan MTs di Kabupaten Ponorogo }\end{array}$ & $\begin{array}{l}\text { Signifikan, } \\
\text { Diterima }\end{array}$ \\
\hline $\mathrm{H}_{2}$ & $\begin{array}{l}\text { Terdapat pengaruh positif } \\
\text { kompetensi terhadap kinerja guru } \\
\text { matematika SMP dan MTs di } \\
\text { Kabupaten Ponorogo }\end{array}$ & $\begin{array}{l}\text { Signifikan, } \\
\text { Diterima }\end{array}$ \\
\hline $\mathrm{H}_{3}$ & $\begin{array}{l}\text { Terdapat pengaruh positif } \\
\text { komitmen profesional terhadap } \\
\text { kinerja guru matematika SMP dan } \\
\text { MTs di Kabupaten Ponorogo }\end{array}$ & $\begin{array}{l}\text { Signifikan, } \\
\text { Diterima }\end{array}$ \\
\hline $\mathrm{H}_{4}$ & $\begin{array}{l}\text { Terdapat pengaruh positif } \\
\text { komitmen profesional guru } \\
\text { terhadap kepuasan kerja guru } \\
\text { matematika SMP dan MTs di } \\
\text { Kabupaten Ponorogo }\end{array}$ & $\begin{array}{l}\text { Signifikan, } \\
\text { Diterima }\end{array}$ \\
\hline
\end{tabular}

Penelitian ini menemukan adanya pengaruh positif variabel kompetensi terhadap komitmen profesional secara signifikan dan tidak dapat ditolak. Temuan ini dapat mengkonfirmasi temuan penelitian yang dilakukan oleh Hall et al. (Khanifar, Jandaghi \& Sojaie, 2010, p.564) yang menyimpulkan bahwa "as employees move to higher levels in their professional and receive increased rewards and status, the costs of leaving the profession may increase and leading to higher Professional Commitment." Artinya, jika seseorang telah meningkatkan level kompe- 
tensinya (profesionalnya) dan menerima penghasilan dan status yang baik, maka harga yang harus dibayar untuk keluar dari profesinya pasti besar. Akibatnya, komitmen profesional seseorang tersebut akan meningkat.

Seperti diketahui, peningkatan kompetensi guru dapat dilakukan dengan berbagai cara, diantaranya dengan mengikuti pelatihan-pelatihan yang sesuai dengan bidang ajar maupun bidang yang relevan dengan pekerjaannya sebagai guru. Pelatihan yang diikuti guru tentu mempunyai pengaruh terhadap statusnya, misalkan sebagai syarat untuk berstatus sebagai guru yang bersertifikasi dan mendapatkan penghasilan tunjangan sertifikasi. Hal ini mengakibatkan tingginya harga atau pengorbanan jika guru tersebut tidak melaksanakan tugasnya dengan baik, atau keluar dari profesinya, sehingga sebagai pengaruhnya, komitmen profesionalnya tentu saja akan meningkat. Temuan penelitian ini yang secara signifikan menyimpulkan bahwa terdapat pengaruh positif kompetensi terhadap komitmen profesional juga mengkonfirmasi hasil penelitian Sheldon (Khanifar, Jandaghi \& Sojaie, 2010, p.564) yang secara lebih tegas mengungkapkan bahwa "professional commitment increases by the work experience.". Pengalaman kerja sebagai salah satu indikator variabel kompetensi gu$\mathrm{ru}$, berpengaruh terhadap komitmen profesional.

Temuan penelitian lainnya mengungkapkan bahwa terdapat pengaruh positif kompetensi terhadap kinerja. Temuan ini tentu mengkonfirmasi banyak penelitian yang sudah dilakukan dan bahkan sudah menjadi wacana yang berkembang di masyarakat bahwa untuk meningkatkan kinerja guru, diperlukan adanya peningkatan kompetensi guru. Pengaruh positif kompetensi terhadap kinerja guru amat mudah dikenali dengan observasi kinerja secara langsung seperti yang dilakukan dalam penelitian ini. Seorang guru yang mempunyai kompetensi tinggi, akan menggunakan segala kemampuannya dalam melaksanakan proses pembelajaran di kelas secara inovatif. Sebagai contoh, seorang guru matematika yang memiliki kompetensi menggunakan media pembelajaran dengan multimedia, akan berusaha untuk menggunakan media itu dalam proses pembelajaran di kelas. Meskipun observasi hanyalah pada sampel data, uji statistik dengan analisis pada sampel data menunjukkan bahwa hasil analisis bisa digeneralisasikan pada populasi secara signifikan. Selain itu, temuan ini dapat mengkonfirmasi teori yang telah dikaji. Resnick (2007, p.66) mengungkapkan pandangannya sebagai berikut: "as individuals become more competent, their performance level should rise. This is consistent with the performance curve which travels through the competence zone." Artinya, individu yang lebih kompeten seharusnya mempunyai kinerja yang lebih baik. Hal ini konsisten dengan kurva kinerja yang menaik pada area kompetensi.

Temuan penting lainnya adalah adanya pengaruh positif komitmen profesional terhadap kinerja secara signifikan dan tidak dapat ditolak. Hal ini mengkonfirmasi temuan penelitian dari. Surana (2010) yang berjudul "Hubungan antara Kemampuan Manajerial Kepala Sekolah, Motivasi Guru, Lingkungan Kerja, dan Komitmen Guru dengan Kinerja Guru SMP di Kabupaten Bantul" yang menemukan bahwa komitmen guru secara individual memiliki pengaruh terhadap kinerja guru SMP di Kabupaten Bantul dan sumbangan efektif komitmen guru terhadap kinerja guru sebesar $11,9 \%$. Konstruk komitmen profesional dalam penelitian ini telah dapat menjembatani kompetensi dan kinerja, yang artinya adalah ketika kompetensi meningkat, maka komitmen profesional juga meningkat, dan ketika komitmen profesional meningkat, maka kinerja juga meningkat. Maknanya, komitmen profesional guru matematika di Kabupaten Ponorogo tidak hanya berupa pernyataan normatif, tapi juga terbukti di lapangan bahwa komitmen mereka merupakan kekuatan untuk meningkatkan kinerja.

Temuan ini juga dapat mengkonfirmasi teori yang telah dikaji. Elias (Khanifar, Jandaghi \& Sojaie, 2010, pp.562-563) mengungkapkan pendapatnya sebagai berikut: "professional commitment has been linked to important outcomes such as improved work performance, reduce turnover intentions and greater satisfaction at both organizational and professional levels." Komitmen profesional telah terkait dengan hasil-hasil penting seperti meningkatnya kinerja, mengurangi niatan untuk melepaskan tanggung jawab dan kepuasan yang lebih besar pada tingkatan organisasi maupun profesi. Pendapat ini secara jelas menyatakan bahwa kinerja dapat dipengaruhi oleh komitmen profesional.

Temuan lainnya dalam penelitian ini adalah adanya pengaruh positif variabel komitmen profesional terhadap kepuasan kerja secara signifikan dan tidak dapat ditolak. Temuan ini mengkonfirmasi penelitian-penelitian tentang hubungan dua variabel ini, diantaranya hasil penelitian yang ditulis oleh Adebomi et al. (2012, p.100) yang menyimpulkan bahwa terdapat relasi yang cukup signifikan antara komit- 
men profesional dan kepuasan kerja. Pengaruh komitmen profesional terhadap kepuasan kerja juga telah diteliti oleh Morrow (Cohen, 2003, p.xi) yang menyatakan bahwa "lack of commitment..is cited as an explanation for...job dissatisfaction." Artinya, rendahnya komitmen cukup bisa menjadi penjelasan bagi ketidakpuasan kerja.

Temuan pengaruh positif komitmen profesional pada kepuasan kerja ini cukup menggembirakan karena variabel kepuasan kerja amatlah penting bagi guru. Kepuasan kerja yang secara signifikan dipengaruhi oleh komitmen profesional- merupakan variabel yang cukup banyak diteliti dalam berbagai bidang, tidak hanya dalam bidang pendidikan. Beberapa penelitian diluar bidang pendidikan menyimpulkan bahwa kepuasan kerja akan menimbulkan lebih banyak perilaku positif bagi seseorang. Seorang guru, tentu harus lebih banyak menampilkan perilaku positif karena seorang guru adalah juga teladan bagi siswa, lingkungan sekolah dan masyarakat.

Di India, temuan mengenai kuatnya hubungan antara komitmen profesional dan kepuasan kerja pernah ditampilkan dalam sebuah artikel yang berjudul "Teaching Competency, Professional Commitment and Job Satisfaction." (www.instablogs.com, diakses tanggal 23 Agustus 2013). Di dalam artikel itu disebutkan bahwa "The result showed very high positive correlation between commitment to profession and job satisfaction level of primary school teachers." Hasil penelitian menunjukkan bahwa terdapat hubungan yang positif antara komitmen profesional dengan kepuasan kerja dari guru. Lebih lanjut, "This means teachers who are satisfied with their job are also equally committed to their profession." Ini artinya, guru yang mempunyai kepuasan kerja juga akan mempunyai komitmen terhadap profesinya.

\section{SIMPULAN DAN SARAN}

\section{Simpulan}

Simpulan dari penelitian ini adalah (1) kompetensi mempunyai pengaruh positif terhadap komitmen profesional guru matematika SMP dan MTs di Kabupaten Ponorogo, (2) kompetensi mempunyai pengaruh positif terhadap kinerja guru matematika SMP dan MTs di Kabupaten Ponorogo, (3) komitmen profesional mempunyai pengaruh positif terhadap kinerja guru matematika SMP dan MTs di Kabupaten Ponorogo, (4) komitmen profesional berpenga- ruh positif terhadap kepuasan kerja guru matematika SMP dan MTs di Kabupaten Ponorogo.

\section{Saran}

Saran yang disampaikan adalah (1) disarankan kepada para pengambil kebijakan di bidang pendidikan khususnya kepala dinas pendidikan di daerah kabupaten/kota untuk terus meningkatkan kompetensi guru matematika melalui berbagai pendidikan dan pelatihan khususnya untuk guru matematika, (2) disarankan kepada para guru matematika untuk terus meningkatkan kompetensi dan komitmen profesionalnya demi peningkatan prestasi matematika siswa, (3) disarankan kepada kepala sekolah untuk melakukan penilaian yang lebih objektif terhadap kinerja guru matematika agar dapat dijadikan acuan dalam proses pembinaan kompetensi guru matematika secara komprehensif.

\section{DAFTAR PUSTAKA}

Adebomi et al. (2012). Job satisfaction and selfefficacy as correlates of job commitment of special education teachers in oyo state. Journal of Education and Practice, 3, 95-104.

Cohen, A. (2003). Multiple commitments in the workplace: An integrative approach. London: Lawrence Erlbaum Associates Publishers.

Hengky Latan. (2012). Structural equation modeling. Bandung: Alfabeta.

Kemendikbud. (2012). Kebijakan pengembangan profesi guru. Jakarta: Badan Pengembangan Sumber Daya Manusia Pendidikan dan Kebudayaan dan Penjaminan Mutu Pendidikan Kemendikbud RI.

Khanifar, H., Jandaghi, G. \& Shojaie, S. (2010). Organizational consideration between spirituality and professional commitment, European Journal of Social Sciences, 12, 558-571.

Marius R. Surana. (2010). Hubungan antara Kemampuan Manajerial Kepala Sekolah, Motivasi Guru, Lingkungan Kerja, dan Komitmen Guru dengan Kinerja Guru SMP di Kabupaten Bantul. Tesis magister, tidak dipublikasikan, Universitas Negeri Yogyakarta, Yogyakarta.

OECD. (2000). First result on pisa. Paris: OECD. 
OECD. (2003). First result on pisa. Paris: OECD.

OECD. (2006). First result on pisa. Paris: OECD.

OECD. (2010). Pisa 2009 result: What students know and can do. Paris: OECD.

Pashwan, A. (2009). Confirmatory factor analysis and structural equation modeling: An introduction. Texas: University of North Texas

Prem. (07 Mei 2009). Teaching competency, professional commitment and job satisfaction. Artikel. Diambil tanggal 23 Agustus 2013, dari www.instablogs.com

Republik Indonesia. (2005). Undang-Undang RI Nomor 14, Tahun 2005, tentang Guru dan Dosen.

Resnick, H. S. (2007). The power of performance management, energizing workplace performance. Ponte Vedra Beach, FL: Work System Associates Inc.

Suyanto. (2012). Uka dan mutu guru kita. Artikel. Diakses pada tanggal 10 September 2012, dari www.dikdas.kemdikbud.go.id 